\title{
Komparasi anak Zina dan Anak Angkat Menurut BW dan Hukum Islam
}

\author{
Imam Supriyadi \\ Institut Agama Islam Nahdlatul Ulama Tuban \\ E-mail: abunakhofa@gmail.com
}

\begin{abstract}
Abstrak: Artikel ini bermula dari, pertama bagaimana agar kita bisa membedakan secara definitif terkait anak zina dan anak angkat dalam perspektif hukum Islam dan BW (Hukum Perdata), kemudian membahas mengenai hak kewarisan anak zina dan anak angkat menurut perspektif hukum Islam dan BW. Anak dalam perspektif BW digolongkan menjadi dua yakni anak sah dan anak tidak sah, yang mana kedudukan anak tidak sah ini menurut perpektif BW tidak dapat mewarisi orang tuanya, kecuali adanya pengakuan dari orang tuanya. Dengan adanya pengakuan tersebut timbullah hubungan keperdataan antara anak luar kawin dan orangtua yang mengakuinya. Sedangkan status anak angkat menurut perspektif Islam itu sendiri ialah hanya sekedar mendapatkan pemeliharaan nafkah (biaya hidup), perawatan terhadap anak dan kasih sayang dari orangtua angkatnya tidak dapat diakui sebagai anak kandung dikarenakan tidak boleh merubah hubungan nasab atau hubungan keturunan antara anak kandung dengan orang tua kandungnya. Sedangkan dalam perpektif BW tidak ada istilah anak angkat, yang ada hanya anak sah dan tidak sah. Pada dasarnya, anak angkat bukanlah ahli waris yang dimaksud dalam Pasal 852 ayat (1) KUHPerdata. Namun, anak angkat dapat memperoleh warisan dengan cara diberi hibah oleh pewaris. Pemberian hibah diatur dalam ketentuan Pasal 957 KUHPerdata.

Kata kunci: Anak zina dan anak angkat, kewarisan BW, kewarisan hukum Islam
\end{abstract}

\section{Pendahuluan}

Dalam ajaran Islam anak adalah nikmat yang dikaruniakan kepada hambanya sekaligus amanah yang harus dijaga dan dipelihara, setiap orang tua pasti memiliki ikatan dengan anaknya, yaitu dengan ikatan istimewa yang tidak terdapat pada hubungan lain.Namun adakalanya dapat terjadi tanpa adanya ikatan yang sah apabila terjadi hubungan yang diharamkan seperti orang yang memiliki anak diluar nikah atau disebut anak hasil zina, adakalanya ikatan antara anak dan orang tua juga tidak 
selalu dengan orang tua kandung, seperti seorang anak angkat pun dapat memiliki ikatan yang kuat terhadap orang tua angkatnya.

Jika membahas masalah anak maka tidak lepas dari masalah pewarisan terhadapnya, al-Quran telah menjelaskan beberapa kelompok ahli waris adalah orang orang yang memiliki ikatan perkawinan dan keluarga terdekat dengan orang yang meninggal dunia. Kelompok ahli waris lain yang tidak dinyatakan dalam Al-Quran dijelaskan Rasul dalam sunnahnya. Pada masa rasul masih hidup penjelasan mengenai hukum kewarisan sudah memadai,karena pada waktu itu masalah yang timbul belum begitu kompleks dan kalaupun ada masalah yang sulit dipecahkan masih ada Rasul yang akan memberikan solusinya. Di Indonesia terdapat beraneka ragam sistem hukum kewarisan yang berlaku bagi warga negara Indonesia. Dengan demikian kompleksnya sosial kemasyarakatan timbul berbagai masalah kewarisan yang harus dipecahkan. Diantara masalahmasalah tersebut ialah masalah pembagian warisan bagi anak hasil zina dan anak angkat baik menurut prespektif Islam dan BW (Hukum Perdata)

\section{Pengertian Anak Zina}

Anak zina adalah anak yang lahir dari suatu perbuatan zina, yaitu hubungan kelamin antara laki- laki dengan perempuan yang tidak terikat dalam nikah yang sah meskipun ia lahir dalam suatu perkawinan yang sah, dengan laki- laki yang melakukan zina atau laki- laki lain. ${ }^{1}$

Dalam Kitab Ahkamul-Mawäriś fi al-Fighi al-Islami disebutkan :

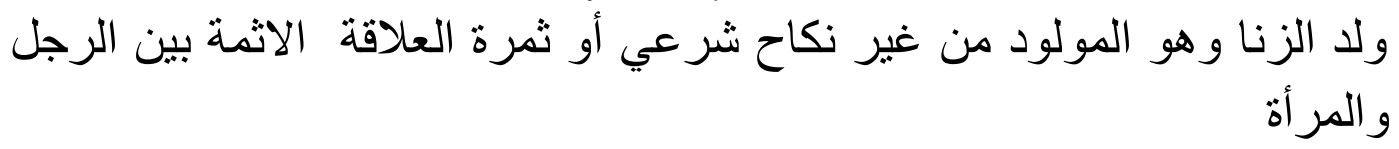

" anak zina adalah anak yang lahir bukan dari hubungan nikah yang sah secara syar'i atau dengan kata lain, buah dari hubungan haram antara laki- laki dan wanita.

Dengan demikian anak hasil zina adalah anak yang lahir dari seorang perempuan yang telah melakukan hubungan kelamin dengan seorang laki-laki,yang keduannya tidak ada pernikahan yang sah. Perbuatan Zina merupakan dosa besar dan akibatnya merusak keturunan dan menggangu keamanan serta mengancam susunan kekeluargaan serta kebersihannya.Islam menjaga kebersihan dalam segala bidang dan yang bersih tidak boleh dicampur dengan yang kotor. ${ }^{2}$.Dalam pandangan Islam terhadap semua anak itu sama,dijelaskan dalam hadis Nabi yang

\footnotetext{
${ }^{1}$ Amir Syarifuddin, Hukum Kewarisan Islam (Jakarta: Kencana 2004), hlm. 148.

2 Fuad Mohd Fakhruddin, Masalah Anak Dalam Hukum Islam,Anak Zina, hlm. 78.
} 
diriwayatkan oleh Abu-Ya'la,al-Tabary dan al-Baihaqi dari al-Aswad bin Shari bahwa Rasullulah saw bersabda,

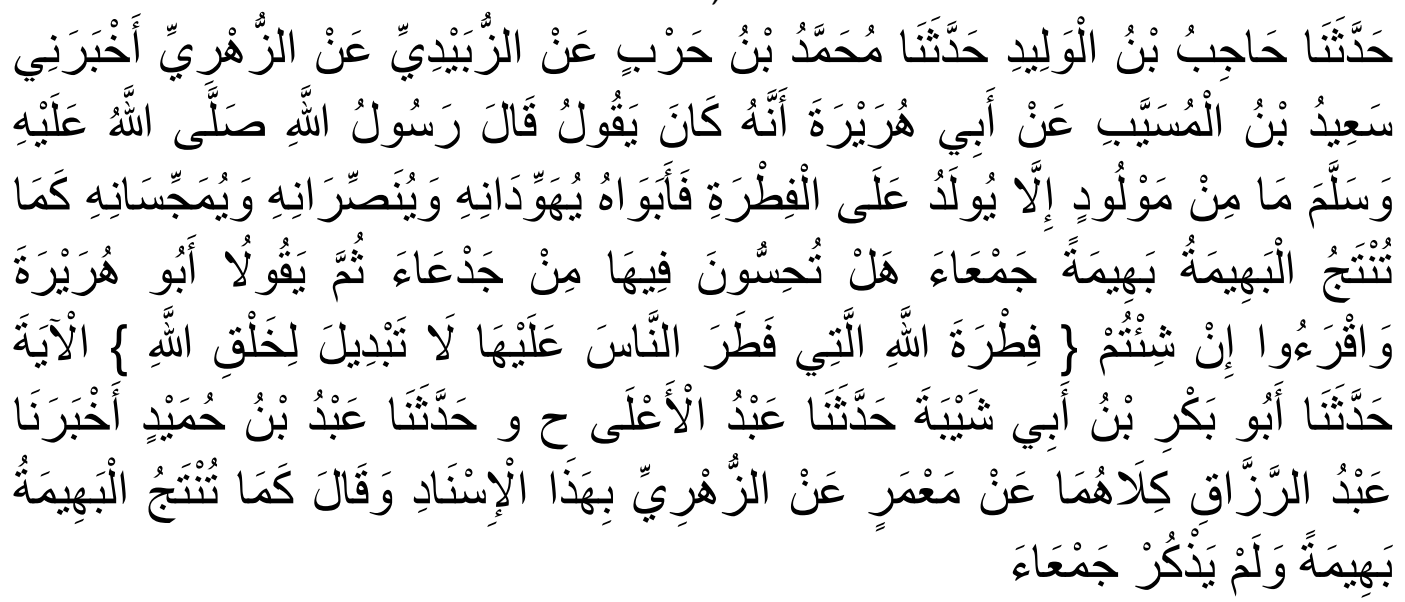

"Semua anak dilahirkan dalam keadaan suci(dari dosa dan noda) dan pembawaan beragama tauhid,sehingga ia jelas bicaranya.Maka kedua orang tuanyalah yang menyebabkkan anaknya menjadi yahudi atau Nasrani atau Majusi." secara hukum anak diluar nikah atau anak hasil zina diakui sama sebagai anak-anak biasa lainnya,karena anak zina tidak bersalah dan yang bersalah adalah orang tuannya.Jadi Islam tidak mengenal adanya dosa turunan,bahwa jika orang tua berdosa maka dosanya akan menurun kepada anaknya dan keturunannya.

\section{Kedudukan Anak Zina}

Dalam hukum Islam anak zina disebut dengan anak mula'anah yang mana anak tersebut anak yang berasal atau yang dilahirkan dari hubungan yang tidak diakui oleh agama dan hukum atau biasanya disebut dengan anak haram. Dalam hukum Islam anak zina mempunyai hak atas waris kepada ibunya.

Menurut Hasbi as- Shiddieqy mendefinisikan anak zina (anak yang tidak diakui agama) sebagai; anak yang dikandung oleh ibunya dari seorang laki-laki yang menggaulinya, tanpa nikah yang dibenarkan oleh syara', oleh karena itu anak zina baik laki- laki maupun perempuan tidak diakui hubungan darah dengan ayahnya, maka ia tidak mewarisi harta ayahnya dan tidak pula dari seorang kerabat ayahnya. Para ulama telah sepakat mengenai seorang anak tidak dapat dinasabkan kepada ayahnya sebagai anak sah, jika anak tersebut dilahirkan kurang dari 6 bulan setelah prosesi akad nikah. Hal ini berarti jika ada anak yang lahir kurang dari 6 bulan maka anak itu tidak sah dan tidak bisa dinasabkan pada Ayahnya. ${ }^{3}$

\footnotetext{
${ }^{3}$ Hasbi Ash Shiddieqy, Figh Mawaris, hlm. 60.
} 
a) Status Nasab Anak Zina

Menurut Imam Malik dan Syafi'i anak yang dilahirkan sbelum enam bulan dari pernikahan orang tuanya maka dinasabkan kepada ibunya saja,karena di duga ibunya telah berhubungan badan dengan orang lain,karena batas waktu hamil minimal enam bulan.Sedangkan menurut Imam Abu Hanifah,anak zina tetap dinasabkan pada suami ibunya tanpa mempertimbangkan waktu masa kehamilan si ibu. ${ }^{4} \mathrm{Jika}$ wanita yang melakukan perbuatan zina tersebut adalah seseorang yang memiliki suami atau dalam masa 'iddah maka ulama sepakat anak tersebut adalah anak suaminya dan pengakuan seseorang terhadap anak tersebut tidak diterima.Sedangkan jika wanita yang melakukan zina tidak memiliki suami atau tidak dalam masa 'iddah ada beberapa pendapat mengenai nasab dari anak yang dikandung oleh wanita tersebut. ${ }^{5}$

Pendapat pertama mengatakan anak tersebut dapat dinasabkan pada seseorang yang mengakuinya sebagai anak jika ia tidak melakukan zina dengan ibunya,namun sebaliknya jika ia mengakui telah berzina dengan ibunya Jumhur ulama mengatakan bahwa anak tersebut tidak dapat dinasabkan padanya.Sedangkan menurut Ishaq bin Rahawaih,Ibnu Taimiyah,dan Ibnu Qayyim anak yang lahir karena perbuatan zina adalah keturunan orang yang mengaku,sebagaimana penetapan nasab anak itu kepada ibunya.

\section{Kewarisan Islam Anak Zina}

Dalam hukum Islam ada tiga faktor yang menyebabkan adanya pewarisan yaitu:

1. Adanya hubungan kekerabatan (Nasab)

2. Adanya perkawinan yang sah

3. Wala' (perwalian)

Sebagai anak zina dalam hukum Islam sama dengan anak mula'anah yaitu anak hasil hubungan di luar pernikahan yang sah. Maka anak tersebut tidak ada bedanya dan sama-sama dilahirkan di luar pernikahan yang sah diantara kedua orang tuanya.Dan keduannya hanya bisa mewarisi dengan ibunya saja. Masing masing terputus hubungan saling

\footnotetext{
${ }^{4}$ Muhammad bin Abdurrahman al Dimasyqi, Figh Empat Mahdzab (Bandung:Pustaka Ilmu,2014), hlm. 374

${ }^{5}$ Muhammad bin Shlmih al -Utsmaimin, Panduan Praktik Hukum Waris (Jakarta :Pustaka Ibnu Katsiir,2012), hlm. 137
} 
mewarisi dengan ayahnya. Oleh karena itu mereka dapat mempusakai hartanya dari pihak ibu, bukan dari pihak ayah sebagaimana dalam zaman jahiliyyah. Landasan yang digunakan para jumhur ulama mengenai ketetapan tersebut yaitu terdapat dalam hadist riwayat $\mathrm{Abu}$ Daud :

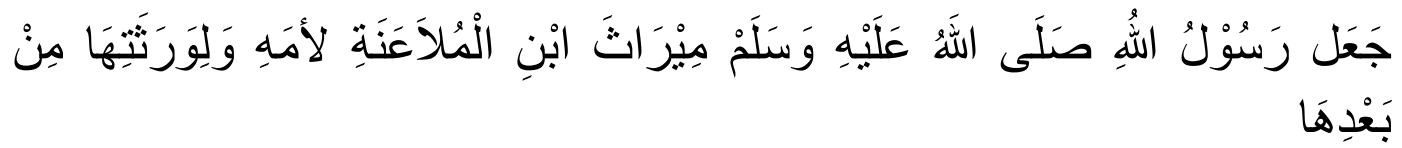

"Rasulullah saw menjadikan hak waris anak mula'anah kepada ibunya dan ahli waris ibu"

Mereka juga dapat mempusakai ibunya dan kerabat ibunya dengan jalan fardh saja tidak dengan jalan lain. Demikian juga dengan ibunya dan kerabat-kerabat ibunya dapat mewarisi harta peninggalannya dengan jalan fardh juga. Hak mereka untuk mempusakai dan di pusakai dengan jalan 'ushubah-nasabiyah'.

Kemudian jika anak hasil zina itu mempunyai saudara seibu lebih dari satu orang maka mereka mendapatkatan bagian besar sepertiga dari harta warisan yang ditinggalkan. Ada suatu hadis yang artinya "Dari Ibnu Abbas Ra,Dari nabi Saw,ia berkata :

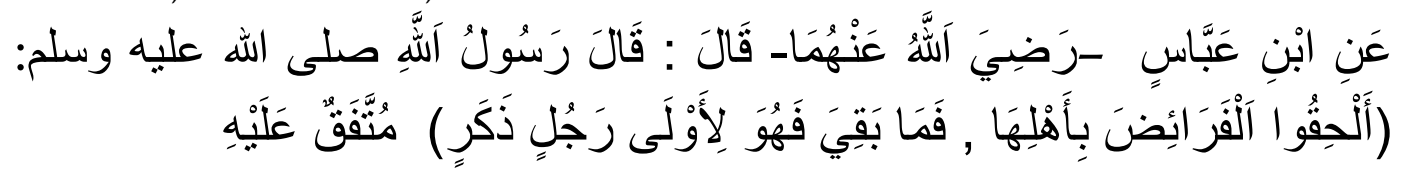

Artinya: Berikanlah Faraidh (bagian yang ditentukan dalam al-Quran)

kepada yang berhak dan sisanya berikanlah kepada keluarga laki-laki terdekat.(HR.Bukhari dan Muslim).

Hadis ini menunjukkan perintah untuk memberikan warisan kepada yang berhak. Dalil-dalil tersebut secara umum telah menjelaskan mengenai pembagian harta warisan orang yang meninggal dunia itu meliputi anak sah maupun anak li'an atau anak hasil zina. Sehingga meskipun seseorang yang meninggal dunia itu mempunyai bapak,namun jika anak tersebut hasil zina maka yang berhak mewarisi harta peninggalannya hanya ibunya saja. Anak hasil zina tersebut hanya dapat waris dan mewarisi dengan ibu yang melahirkannya dan atau dengan keluarga dari pihak ibunya. Jadi anak hasil zina tidak dapat waris dan mewarisi dengan laki-laki yang menyebabkan dia lahir. Baik anak hasil zina tersebut lahir dari perempuan yang merdeka maupun budak. ${ }^{6}$ Para ulama Fikih berbeda pendapat tentang warisan untuk anak yang lahir

${ }^{6}$ Muhammad Nashiruddin al-Albhani, Shahih Sunan at Tirmidzi,penerjemah: Fachrurazi (Jakarta :Pustaka Azzam,2006),Jilid 2,cet.Ke-1, hlm. 639 
karena zina. Secara umum,pendapat para ulama Fikih dapat dikelompokkan menjadi tiga pendapat sebagai berikut: ${ }^{7}$

Pendapat Ulama Fiqh mengenai Warisan untuk anak diluar nikah atau anak zina

\begin{tabular}{|c|c|c|}
\hline Pendapat pertama & Pendapat Kedua & Pendapat ketiga \\
\hline $\begin{array}{l}\text { Abu Hanifah, } \\
\text { Malik,dan Syafi'i } \\
\text { berpendapat bahwa } \\
\text { anak tersebut dapat } \\
\text { mewarisi dari ibu dan } \\
\text { kerabat ibunya,dan ibu } \\
\text { serta kerabat ibunya } \\
\text { pun dapatmewarisi } \\
\text { darinya,sesuai dengan } \\
\text { kaidah waris-mewarisi } \\
\text { yang sudah di } \\
\text { ketahui.Ini adalah } \\
\text { pendapat Zaid bin } \\
\text { Tsabit dalam satu } \\
\text { riwayat dari Ali r.a. }\end{array}$ & $\begin{array}{l}\text { Ahmad bin Hanbal } \\
\text { berpendapat bahwa } \\
\text { anak yang lahir dari } \\
\text { perbuatan zina dapat } \\
\text { diwarisi dengan cara } \\
\text { ashabah.Ashabahnya } \\
\text { adalah mereka yang } \\
\text { menjadi ashabah } \\
\text { ibunya atau mereka } \\
\text { yang mewarisi dari } \\
\text { ibunya.Sebagaimana } \\
\text { orang berkata "Jika } \\
\text { anda ingin } \\
\text { mengetahui ashabah } \\
\text { anak li'an, lihatlah } \\
\text { ashabah ibunya kalau } \\
\text { ibunya wafat.Itulah } \\
\text { yang menjadi ashabah } \\
\text { anak li'an. }\end{array}$ & $\begin{array}{l}\text { Ahmad bin Hambal } \\
\text { berpendapat bahwa } \\
\text { ashabah anak yang } \\
\text { lahir karena } \\
\text { perbuatan zina } \\
\text { adalah ibunya karena } \\
\text { ibu bagi mereka } \\
\text { sama sepertikedua } \\
\text { orangtuanya.yakni } \\
\text { ayah dan ibu.jika } \\
\text { tidak ada } \\
\text { ibu,ashabahnya } \\
\text { adalah mereka yang } \\
\text { menjadi ashabah } \\
\text { ibu.Pendapat ini juga } \\
\text { disampaikan oleh } \\
\text { beberapa tabi'in,di } \\
\text { antaranya Hasan dan } \\
\text { Ibn Sirin. }\end{array}$ \\
\hline
\end{tabular}

\section{Konsepsi Perlindungan Anak Zina dalam Perspektif Islam}

Ketentuan yang diatur dalam KHI Dalam bidang perkawinan tampak bahwa secara garis besar berusaha memberikan nilai-nilai Islam terhadap hal-hal yang belum diatur dalam undang-undang perkawinan. Disamping itu, KHI tentunya berfungsi memberikan penegasan serta Penjabaran terhadap undang-undang Perkawinan dan sekaligus menambahkan materi-materi tertentu sesuai dengan hukum Islam. namun sebelumnya perlu diungkapkan problematika penerapan materi undang-undang akibat pemahaman masyarakat terhadap kitab-kitab fikih atau pemikiran mazhab fikih antara lain masalah pencatatan perkawinan. Mencermati

7 Komite Fakultas Syariah Universitas Al-Azar, Hukum Waris (Jakarta:Senayan Abadi Publishing,2009), hlm. 137 
materi Undang-Undang Perkawinan dan KHI, meskipun undang-undang Perkawinan dan KHI bertujuan untuk melindungi hak-hak perempuan. Dari kewenangan kaum laki-laki, namun kenyataannya pengaruh sosial budaya dan ekonomi ternyata tidak mengurangi tindakan melawan hukum seperti perzinaan yang mempengaruhi status anak yang dilahirkan berakhir anak yang dihasilkan tidak memiliki hubungan perdata dengan ayah biologisnya. Undang-Undang Nomor 23 Tahun 2002 tentang perlindungan anak telah menegaskan bahwa pertanggungjawaban orangtua,masyarakat,keluarga, pemerintah dan negara merupakan rangkaian kegiatan yang dilaksanakan secara terusmenerus demi melindungi hak anak. ${ }^{8}$

Keberadaan undang-undang Perlindungan Anak masih diragukan untuk memberi perlindungan kepada anak, di dalamnya tidak memberikan penjelasan secara spesifik anak dan luar nikah, perlindungan yang dimaksud diperuntukkan kepada anak-anak yang pada umumnya nya yang mana dalam undang-undang itu tidak memberikan pengecualian kepada anak-anak diluar nikah, sehingga dirasa sangat penting tanpa harus menerima perlakuan diskriminatif antara anak zina maupun anak sah. Anak yang lahir diluar nikah masih sering mengalami perlakuan yang diskriminatif, kekerasan dan ketidakadilan bahkan sampai menjadi korban dari sistem peradilan.

Belum ada kebijakan signifikan yang memihak pada ada perlindungan keberadaan anak diluar nikah dalam masyarakat. Seolaholah sepanjang hidup anak-anak diluar nikah dipaksa menanggung beban dosa kedua orang tuanya dan mendapat stigma sebagai anak hasil zina atau anak haram. Padahal tidak ada satupun anak yang dapat memilih di keluarga mana akan dilahirkan karena itu segala bentuk kesalahanan dan stigma yang seharusnya di berikan kepada orang tuanya bukan kepada anak. Anak dalam agama apapun adalah suci dan tidak menanggung dosa akibat perbuatan kedua orang tuanya. ${ }^{9}$

Perlindungan anak Luar nikah dalam konteks ini sangat diperlukan agar tidak ada ada orang yang yang memperlakukan mereka secara diskriminatif, tidak adil dan menempatkan posisinya sama dengan anakanak yang lainnya. Memberikan perlindungan terhadap anak diluar

${ }^{8}$ Komite Fakultas Syariah Universitas Al-Azar. hlm. 137

9 Siti Musdah mulia, Muslimah Reformis:Perempuan Pembaru Keagamaan (Bandung:Mizan 2005), hlm. 421-422I 
nikah tidak berarti mendukung meluasnya pergaulan bebas akan tetapi harus dipikirkan konsep-konsep yang dapat mengatasi pergaulan bebas itu dengan memberikan pembinaan dan pendidikan agama berisikan pesan-pesan moral baik kepada laki-laki maupun perempuan agar dapat mengatasi permasalahan pergaulan bebas remaja.Pencantuman anak diluar nikah pada akta kelahiran harus dicarikan formulasi tanpa harus menyebutkan status anak tersebut, anak diluar nikah juga memiliki hak kemanusiaan dan tidak harus diperlakukan secara tidak manusiawi. Perlakuan Seperti itu perlu dikritisi mengingat kesalahan orang tuanya diwariskan kepada anak diluar nikah, sehingga hukum dan dipersalahkan akibat perbuatan orang tuanya yang melakukan hubungan seksual tanpa melakukan perkawinan yang sah atau zina.Tindakan demikian tentu saja dapat mengaburkan cita-cita hukum yang tidak memberikan kemanfaatan, keadilan dan kepastian hukum.Membiarkan tindakan itu berarti ada kesengajaan menelantarkan anak diluar nikah.

Peraturan hukum di Indonesia yang diatur dalam pasal 53 ayat 1 Kompilasi Hukum Islam telah melegalkan perkawinan wanita hamil diluar nikah sebagai upaya memberikan perlindungan agar terbebas dari rasa malu, aib dan celaan masyarakat. Hal ini, adalah ironis di satu sisi perkawinan wanita hamil dilegalkan agar anak dalam kandungan nya tetap menjadi anak sah sementara di sisi lain anak diluar nikah masih terus dipersengketakan statusnya. Anak diluar nikah memang harus membangun sebuah komitmen untuk diperlakukan secara manusiawi sesuai dengan Undang-Undang Dasar Republik Indonesia tahun 1945 yang selanjutnya dipertegas kembali dalam Undang-Undang perlindungan anak sehingga mendapatkan hak-hak yang melekat pada dirinya yakni hak waris, hak perwalian, dan hak mendapatkan nafkah lahir dan batin dari ayah biologisnya dan hak sipil termasuk akta kelahiran. Keberpihakan pada perlindungan anak di luar nikah perlu terus ditegakkan. Dalam berbagai perundang-undangan dalam peraturan seperti Undang-Undang perkawinan, Perlindungan Anak dan peraturan catatan Sipil selalu disebut soal anak yang lahir dalam perkawinan yang sah sehingga tidak sedikitpun celah bagi perlindungan anak yang lahir diluar perkawinan.

\section{Pengertian Anak Angkat}

Anak angkat seringkali dipahami sebagai pengambilan anak orang lain untuk dijadikan sebagai seperti anak sendiri. Sedangkan menurut 
pengertian beberapa ahli seperti:

Soerojo Wignjodipoero mengatakan bahwa pengangkatan anak adalah suatu perbuatan atau tindakan pengambilan anak orang lain ke keluarga sendiri sedemikian rupa sehingga antara orang yang memungut anak dan anak yang dipungut itu timbul suatu hukum kekeluargaan yang sama seperti yang ada antara orang tua dengan anak kandungnya sendiri. Sedangkan menurut Helman Hadi Kusuma mengatakan anak adalah anak orang lain yang dianggap anak sendiri oleh orang tua angkat dengan cara menurut hukum adat setempat dikarenakan untuk tujuan kelangsungan keturunan dan atau pemeliharaan atas harta benda kekayaan rumah tangga.

Dalam agama Islam pada esensinya tidak melarang praktek pengangkatan anak atau adopsi, sejauh tidak mempengaruhi dan tidak merubah hubungan nasab dan hubungan keturunan antara anak kandung dengan orang tua kandungnya, atau hungan antara anak dengan orang tua aslinya. Akan tetapi dalam ajaran Islam akan melarang pengangkatan anak dikala pengangkatan anak itu akan menimbulkan masalah dan problem, yaitu jikalau berakibat putusnya hubungan anak itu dengan orang tua kandungnya. ${ }^{10}$

Larangan pengangkatan anak dalam arti yang benar-benar menjadi anak kandung ini didasarkan pada firman Allah dalam Surat Al-Ahzab ayat 4 , yang artnya sebagai berikut:

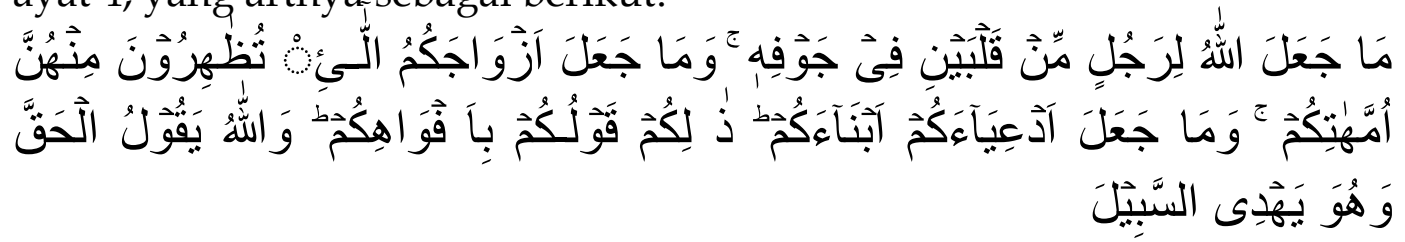

"Allah tidak menjadikan bagi seseorang dua hati dalam rongganya; dan Dia tidak menjadikan istri-istrimu yang kamu zihar itu sebagai ibumu, dan Dia tidak menjadikan anak angkatmu sebagai anak kandungmu (sendiri). Yang demikian itu hanyalah perkataan di mulutmu saja. Allah mengatakan yang sebenarnya dan Dia menunjukkan jalan (yang benar)."11

Pengangkatan anak telah menjadi tradisi di kalangan mayoritas masyarakat Arab dengan istilah tabanni yang berarti mengambil anak angkat. Secara terminology tabanni menurut Wahbah Al-Zuhaili adalah

\footnotetext{
${ }^{10}$ Ahmad Rofiq, Fikih Mawaris (Jakarta, PT Raja Grafindo Persada, 2002).

11https://kalam.sindonews.com/ayat/4/33/al-ahzab-ayat-4
} 
pengangkatan anak (tabanni) "Pengambilan anak yang dilakukan oleh seseorang terhadap anak yang jelas nasabnya, kemudian anak itu dinasabkan kepada dirinya". Pengangkatan anak dalam pengertian demikian jelas bertentangan dengan hukum Islam, maka unsur menasabkan seorang anak kepada orang lain yang bukan nasabnya harus dibatalkan. ${ }^{12}$

Syeh Mahmud Syaltut, berpendapat bahwa ada dua pengertian anak angkat yang berbeda, yaitu: pertama: At-Tabanni adalah seseorang yang mengangkat anak, yang diketahui bahwa anak itu termasuk anak orang lain, kemudian ia memperlakukan anak tersebut sama dengan anak kandungnya, baik dari kasih sayang maupun nafkah (biaya hidup) tanpa ia memandang perbedaan. Meskipun demikiandalam agama Islam tidak menganggap sebagai anak kandung, karena hal tersebut tidak dapat disamakan statusnya dengan anak kandung. Bentuk pengangkatan anak yang kedua: bahwa At-Tabanni adalah seseorang yang tidak memiliki anak, kemudian menjadikan seseorang anak orang lain sebagai anaknya, padahal mengetahui bahwa anak itu bukan anak kandungnya, lalu menjadikan sebagai anak sah. ${ }^{13}$ Pendidikan, pelayanan kesehatan, dan hak-haknya dengan status anak kandung.

Dari definisi diatas dapat disimpulkan bahwa status anak angkat itu hanya sekedar mendapatkan pemeliharaan nafkah (biaya hidup), perawatan terhadap anak dan kasih sayang dari orangtua angkatnya, dan ada juga yang menggambarkan pengangkatan anak sebagaimana yang terjadi pada zaman jahiliyah yang mempersamakan status anak angkat sebagai anak kandung dan memutuskan hubungan darah dengan orang tua kandungnya. Oleh karena itu, anak angkat berhak menjadi ahli waris dan memperoleh warisan sebagaimana hak warisan yang diperoleh anak kandung.

Menurut Hukum Islam pengangkatan anak hanya dapat dibenarkan apabila memenuhi ketentuan-ketentuan sebagai berikut:

1. Tidak memutuskan hubungan darahatau nasab antara anak yang diangkat dengan orang tua biologis dan keluarganya.

2. Anak angkat tidak berkedudukan sebagai pewaris orang tua angkat, melainkan tetap sebagai pewaris dari orang tua kandungnya,

\footnotetext{
${ }^{12} \mathrm{Ahmad}$ Kamil, dan M. Fauzan. Hukum Perlindungan dan Pengangkatan Anak di Indonesia (Jakarta:PT Raja Grafindo, 2010), hlm.96

${ }^{13}$ Ahmad Kamil, dan M. Fauzan. hlm.104.
} 
demikian juga orang tua angkat tidak berkedudukan sebagai pewaris dari anak angkatnya.

3. Anak angkat tidak boleh menggunakan nama orang tua angkatnya secara langsung kecuali sebagai tanda pengenal/alamat.

4. Orangtua angkat tidak dapat bertindak sebagai wali dalam perkawinan terhadap anak angkatnya.

Adapun pendapat Majelis Ulama yang dituangkan dalam surat Nomor U335/MUI/VI/1982 Tanggal 10 Juni 1982, adalah sebagai berikut:

1. Adopsi yang bertujuan pemeliharaan, pemberian bantuan dan lainlain yang sifatnya untuk kepentingan anak angkat diperbolehkan menurut Hukum Islam.

2. Anak-anak yang beragama Islam hendaknya dijadikan anak angkat (adopsi) oleh ayah/ibu angkat yang beragama Islam.

3. Pengangkatan anak angkat (adopsi) tidak akan mengakibatkan hak kekeluargaan yang biasa dicapai dengan nasab keturunan. Oleh karena itu adopsi tidak mengakibatkan hak wali/wali mewali dan lain-lain. Karena itu ayah/ibu angkat jika akan memberikan apa-apa kepada anak angkatnya hendaklah dilakukan padamasa sama-sama hidup sebagai hibah biasa.

4. Adapun adopsi yang dilarang, adalah adopsi oleh orang-orang yang berbeda agama. Pengangkatan anak angkat Indonesia oleh orangorang Eropa dan Amerika atau lain-lainnya.

Berdasarkan uraian diatas, Islam tidak melarang memberikan berbagai bentuk bantuan atau jaminan penghidupan oleh orang-tua angkatnya terhadap anak angkatnya anatara lain berupa:

1. Pemberian hibah kepada anak angkat untuk bekal hidupnya dikemudian hari.

Hibah adalah pemberian sesuatu dari seseorang kepada orang lain dan diserahkan kepemilikannya secara langsung ketika dia masih hidup dengan niat sadaqah. Hal ini sebagaimana yang telah dijelaskan dalam kitab al-Fiqhu al-Manhaji Ala Madzhabi al-Imam asySyafi'iy (115/6):

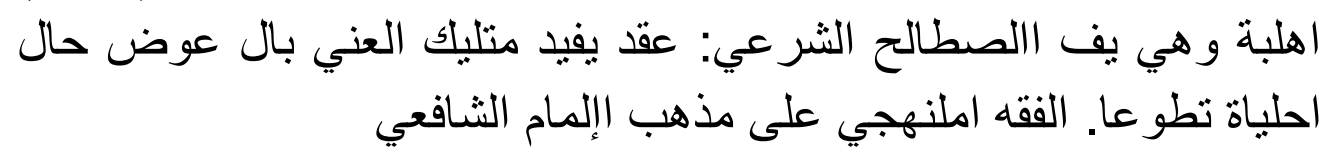

“ Hibah secara istilah syar'i adalah akad kepemilikan suatu benda dengan tanpa imbalan dan diserahkan semasa masih hidup sebagai bentuk sadaqah tathawwu'." 
Jadi pada intinya hibah adalah pemberian sesuatu yang dilakukan oleh si pemilik harta sebelum meninggal dunia. Maka ketika orang tua sebelum wafat mengumpulkan semua anak-anaknya dan ingin memberi harta atau bagi-bagi harta kepada mereka maka akad yang seperti ini disebut dengan hibah. Bukan bagi-bagi waris. Dari contoh di atas bisa disimpulkan bahwa poin dasar terkait hibah adalah pemberian orang tua kepada anak-anaknya pada saat masih hidup dan kepemilikannya langsung berpindah saat itu juga. ${ }^{14}$

2. Pemberian wasiat kepada anak angkat dengan ketentuan ketentuan tidak lebih dari 1/3 (sepertiga) harta kekayaan orangtua angkatnya.

Wasiat adalah pemberian sesuatu dari seseorang kepada orang lain ketika dia masih hidup dengan niat sadaqah. Akan tetapi penyerahan kepemilikannya dilakukan ketika setelah meninggal dunia. Hal ini sebagaimana yang telah dijelaskan dalam kitab al-Fiqhu al-Manhaji Ala Madzhabi al-Imam asySyafi'iy (41/5) :

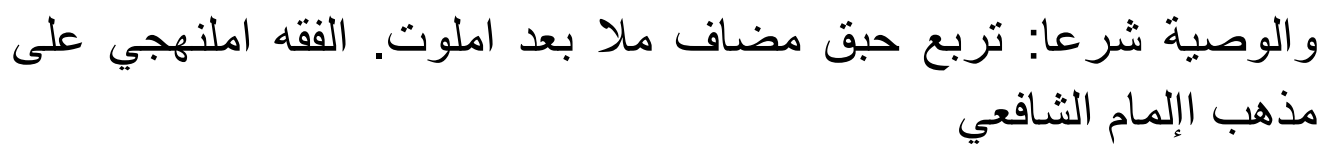

“Wasiat secara istilah syar'i adalah akad tabarru' atas hak kepemilikan harta yang diserahkan setelah meninggal dunia."

Jadi pada intinya wasiat adalah pemberian yang dilakukan oleh si pemilik harta dengan syarat penyerahan kepemilikan harta tersebut dilakukan setelah si pemilik harta meninggal dunia. Sebagai contoh ketika orang tua sebelum wafat mengumpulkan semua anak-anaknya dan mengatakan "Nak, nanti jika bapak meninggal dunia tolong berikan sebagian harta bapak untuk masjid samping rumah ya?". Nah, yang seperti ini namanya adalah wasiat. Sebagai anak yang diwasiati orang tuanya seperti itu maka hukumnya wajib untuk menjalankan wasiat orang tuanya. Dan apabila orang tua hendak berwasiat sesuatu kepada anaknya sebaiknya menghadirkan beberapa saksi dari anak-anaknya atau orang lain juga. Bila perlu dibuatkan juga surat resmi wasiatnya. Agar kedudukan wasiat ini juga dianggap kuat nantinya secara hukum negara kita. ${ }^{15}$

14 Muhammad Ajib. Perbedaan Antara Hibah, Wasiat, dan Waris (Jakarta: Rumah Fiqh Publishing, 2020), hlm. 9

${ }^{15}$ Muhammad Ajib. hlm.11 


\section{Kewarisan Islam Anak Angkat}

Para Ahli Hukum Islam di kalangan Madzhab Maliki, Syafi'i, dan Hanbali sebagaimana dikemukakan Abdurrahman al-Jaziri memberikan definisi yang lebih rinci bahwa wasiat merupakan suatu transaksi yang mengharuskan seseorang yang menerima wasiat, berhak memiliki sepertiga harta peninggalan orang yang menyatakan wasiat setelah ia meninggal. Menurut Abdul Manan, wasiat dibuat untuk menghindari persengketaan, sebagai perwujudan kasih sayang orang yang berwasiat, atau memenuhi keinginan pewasiat yang belum terpenuhi semasa hidup. ${ }^{16}$

Sedangkan menurut ketentuan Pasal 1 huruf f KHI disebutkan bahwa wasiat adalah pemberian suatu benda dari pewaris kepada orang lain atau lembaga yang akan berlaku setelah pewaris meninggal dunia. Adapun jumlah harta yang boleh diwasiatkan, menurut Jumhur Ulama, tidak boleh lebih dari sepertiga harta pusaka, apabila memiliki ahli waris. ${ }^{17}$ Jika melebihi ketentuan, maka harus ada izin dari semua ahli waris. Hal ini juga diatur dalam Pasal 201 KHI yang menyatakan apabila wasiat melebihi sepertiga dari harta warisan sedangkan ahli waris ada yang tidak menyetujui, maka wasiat hanya dilaksanakan sampai sepertiga harta warisnya. Pada dasarnya memberikan wasiat itu adalah atas tindakan ikhtiyâriyah yakni suatu tindakan atau perbuatan yang dilakukan atas dorongan kemauan sendiri. Dalam keadaan bagaimanapun juga, penguasa atau hakim tidak dapat memaksa seseorang untuk memberikan wasiat. Menurut asalnya, hukum wasiat itu adalah suatu perbuatan yang dilakukan dengan suka rela dalam segala keadaan, karenanya tidak ada dalam syari'at Islam sesuatu wasiat yang wajib dilakukan dengan jalan putusan hakim. ${ }^{18}$

\section{Konsep Wasiat Wajibah}

Wasiat wajibah merupakan suatu pelaksanaan wasiat atau suatu pesan yang harus dilaksanakan dan ditujukan kepada orang yang ditinggalkan (orang yang masih hidup) akan memberikan harta peninggalannya kepada anak angkat. Wasiat wajibah juga dapat diartikan sebagai suatu pemberian yang wajib kepada ahli waris atau kaum

\footnotetext{
${ }^{16}$ Abdul Manan, Aneka Masalah Hukum Perdata Islam di Indonesia (Jakarta:Kencana, 2006), hlm. 150

17 Abdul Manan, hlm. 170

${ }^{18}$ Fatchur Rahman, Ilmu Waris, (Bandung: AlMa'arif, 1994), hlm. 62.
} 
keluarga terutama cucu yang terhalang dari menerima harta warisan karena ibu atau ayah mereka meninggal sebelum kakek atau nenek mereka meninggal atau meninggal bersamaan.

Pembagian harta warisan bagi anak angkat menurut Kompilasi Hukum Islam adalah dengan jalan melalui hibah atau dengan jalan wasiat wajibah dengan syarat tidak boleh melebihi $1 / 3$ (sepertiga) dari harta warisan orang tua angkatnya, hal ini untuk melindungi ahli waris lainnya.

Dasar legalitas yang mendukung dalam mendasari keberadaan wasiat wajibah, diantaranya :

Q.S Al Baqarah Ayat 180

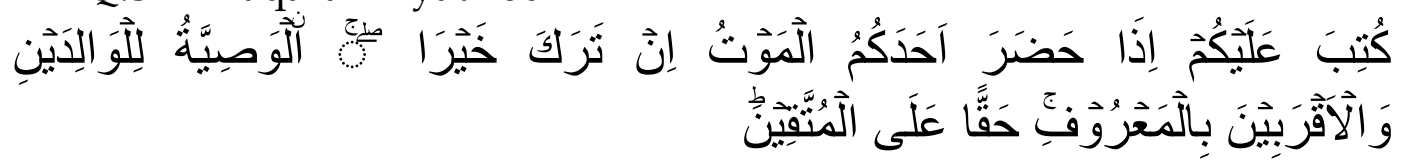

“ Diwajibkan atas kamu, apabila maut hendak menjemput seseorang di antara kamu, jika dia meninggalkan harta, berwasiat untuk kedua orang tua dan karib kerabat dengan cara yang baik, (sebagai) kewajiban bagi orang-orang yang bertakwa."19

Hadis

عن ابن عمر رضي الله قال : قال رسول الله صلى الله عليه و سلم ما حقُّ امرئٍ

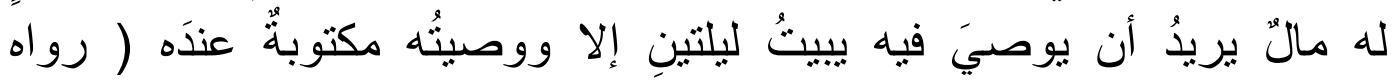

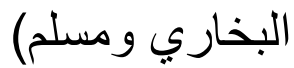

“ Dari Ibnu Umar R.A berkata : Rasulullah SAW bersabda : " tidak ada hak bagi seseorang muslim yang memiliki sesuatu yang akan diwariskannya, melewati sampai dua malam, kecuali wafatnya tertulis disisinya." 20 H.R Bukhari dan Muslim)

Pandangan Hasbi Ash-Shiddiedy mengenai syarat-syarat yang harus dipenuhi sebelum melaksanakan wasiat wajibah, antara lain:

(1) Harta yang akan diberikan kepada seseorang hanya dapat disalurkan melalui wasiat, bukan waris. Jika ia memperoleh harta waris maka tidak wajib diberlakukan wasiat wajibah terhadapnya.

(2) Orang yang meninggal belum memberikan harta kepada orang tersebut melalui cara yang lain, seperti hibah. Jika telah diberikan melalui hibah dan ternyata kurang, maka wajib dipenuhi hingga sepertiga bagian. ${ }^{21}$

\footnotetext{
${ }^{19}$ https://kalam.sindonews.com/ayat/180/2/al-baqarah-ayat-180

20 Muhammad Fu'ad Abdul Baqi Al- Lu'lu' Wal Marjan diterjemahkan oleh Muslich Shabir, cet. 1 (Semarang: Al- Ridho, 1993) Juz 2 Kitab Wasiat, Hadis ke 1052, hlm. 390.

${ }^{21}$ Muhammad Hasbi Ash-Shiddieqy, hlm. 277.
} 


\section{Wasiat Wajibah Menurut Kompilasi Hukum Islam}

Kompilasi Hukum Islam (KHI) menetapkan bahwa antara anak angkat dan orang tua angkat terbina hubungan saling berwasiat. Dalam Pasal 209 ayat (1) dan ayat (2) berbunyi:

(1) Harta peninggalan anak angkat dibagi berdasarkan Pasal 176 sampai dengan 193 tersebut di atas, sedangkan terhadap orang tua angkat yang tidak menerima wasiat wajibah diberi wasiat wajibah sebanyakbanyaknya $1 / 3$ dari harta warisan anak angkatnya.

(2) Terhadap anak angkat yang tidak menerima wasiat diberi wasiat wajibah sebanyak-banyaknya $1 / 3$ dari harta warisan orang tua angkatnya.

Adapun ketentuan sepertiga (1/3) ini berdasarkan Hadis yang diriwayatkan oleh Sa'ad bin Abi Waqqash :

حدثنا محمد بن كثير أخبرنا سفيان عن سعدابن إبراهيم عن عامر بن سعد

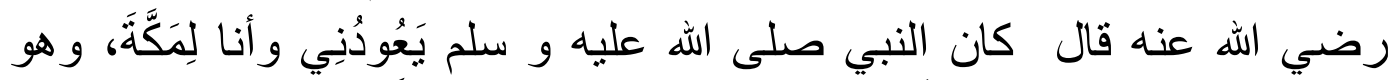

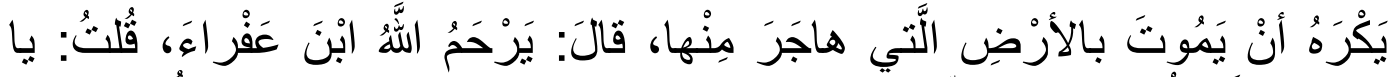

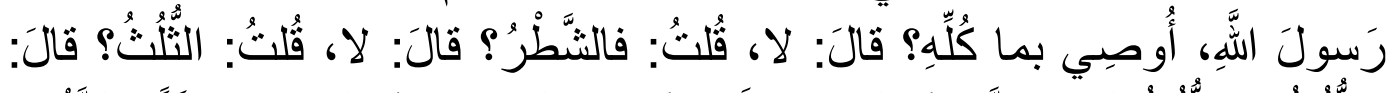

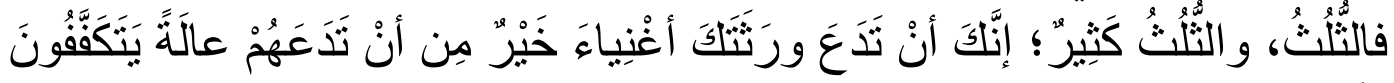

$$
\text { النَّاسن في أبْدِيهِْْ (رو اه البخاري) }
$$

"telah datang nabi muhammmad SAW untuk menengok aku, sedang aku ada di Mekkah, beliau tidak suka meninggal dunia di tanah yang beliau hijrah darinya. Beliau bersabad :" semoga Allah mengasihi anak laki- laki dari Afra, aku lantas berkata :" Ya Rasullallah, apakah aku harus berwasiat dengan seluruh hartaku? Beliau menjawab : " tidak" aku berkata : "separuhnya?", Beliau menjawab : "tidak", aku berkata sepertiga ?" Beliau menjawab " ya sepertiga" . Dan seperti itu sudah banyak, sesungguhnya bila engkau meninggalkan ahli warismu dalam keadaan kaya itu lebih baik daraipada engkau tinggalkan mereka dalam keadaan miskin, meminta- minta dengan menengadahkan tangannya. " (H.R Bukhari) ${ }^{22}$

Dalam Kompilasi Hukum Islam orang tua angkat secara serta merta dianggap telah meninggalkan wasiat (karena itu diberi nama wasiat wajibah) maksimal sebanyak 1/3 dari harta yang ditinggalkan untuk anak angkatnya, atau sebaliknya anak angkat untuk orang tua angkatnya, dimana harta tersebut dalam sistem pembagiannya bahwa sebelum

22 Al- Bukhori, Shohih Al-Bukhori, Juz 3. ( Beirut, Darul Fikr 2006), hlm. 305. 
dilaksanakan pembagian warisan kepada para ahli warisnya, maka wasiat wajibah harus ditunaikan terlebih dahulu. Wasiat wajibah sebagai wasiat yang pelaksanaannya tidak dipengaruhi atau tidak bergantung kepada kemauan atau kehendak yang meninggal dunia. Wasiat wajibah adalah suatu wasiat yang diperuntukkan kepada ahli waris atau kerabat yang tidak memperoleh bagian harta warisan dari orang yang wafat, karena adanya suatu halangan syara'.

\section{Komparasi Kewarisan anak zina menurut Hukum Perdata ( BW)}

Di dalam Kitab Undang-Undang Hukum Perdata anak dapat digolongkan menjadi 2 golongan yaitu:

1) Anak sah yakni anak yang dilahirkan berdasarkan perkawinan yang sah menurut undang-undang. Hal ini sejalan dengan bunyi Pasal 250 KUHPerdata

2) Anak tidak sah yakni anak uang dilahirkan tidak didasarkan pada perkawinan yang sah.

a. Anak yang pada waktu lahirnya orangtuanya tidak kawin secara syah serta tidak kawin pula dengan orang lain/ sedang tidak ada hubungan perkawinan. Anak semacam ini disebut dengan natuurlijk kind (anak alami). Hal ini diatur dalam Pasal 280 KUHPerdata;

b. Anak yang pada waktu lahirnya orangtuanya atau salah satu dari orangtuanya terikat dalam ikatan perkawinan dengan orang lain. Anak semacam ini disebut dengan overspeleg kind (anak zina),Hal ini diatur dalam Pasal 283 KUHPerdata;

c. Anak yang pada waktu lahirnya orangtuanya tidak boleh kawin, sebab pertalian darahnya melarangnya kawin. Anak semacam ini disebut blodsceneg (anak sumbang). Hal ini diatur dalam Pasal 283 KUHPerdata.

Dari kedua golongan anak berdasarkan Kitab Undang-Undang Hukum Perdata tersebut diatas hanya anak sahlah yang bisa menjadi ahli waris dari orangtuanya. Sedangkan untuk anak tidak sah mereka tidak bisa mewaris. Namun berdasarkan Pasal 272 KUHPerdata dapat diketahui bahwa dalam hukum Perdata terdapat anak yang dapat dilakukan pengakuan dan dapat disahkan yakni natuurlijk kind, dan juga terdapat anak-anak yang tidak dapat dilakukan pengakuan terhadapnya yakni overspeleg kind dan blodsceneg.

Dengan adanya pengakuan tersebut timbullah hubungan keperdataan 
antara anak luar kawin dan orangtua yang mengakuinya sebagaimana yang diatur dalam Pasal 280 KUHPerdata. Dengan adanya hubungan keperdataan tersebut maka membawa akibat salah satunya adalah hubungan kewarisan. Jadi dapat disimpulkan bahwa anak tidak sah baru bisa mewaris setelah mendapat pengakuan dari orangtua yang mengakui, dan hanya anak tidak sah yang diatur dalam Pasal 280 KUHPerdata yakni anak luar kawin atau anak alami yang bisa diakui dan kemudian disahkan.

Dalam hukum Perdata anak luar kawin dapat memporoleh warisan dengan semua golongan waris yang terdapat dalam hukum Perdata yakni Golongan I, Golongan II, Golongan III, Golongan IV.

Dasar pengaturan warisan terhadap anak luar kawin berada pada Pasal 863 KUHPerdata.

1) Anak Luar Kawin Mewaris Bersama Golongan I

Anak luar kawin dapat mewaris dengan golongan satu yang terdiri dari anak sah beserta keturunannya dan janda (janda yang dimaksud disini adalah suami/istri pewaris). Hak waris yang diterima oleh anak luar kawin adalah $1 / 3$ dari hak yang mereka sedianya terima, seandainya ia adalah anak sah.

2) Anak Luar Kawin Mewaris Bersama Golongan II

Dalam hal anak luar kawin mewaris dengan golongan II besar warisan yang diterima adalah $1 / 2$ dari warisan yang ditinggalkan oleh pewaris.

3) Anak Luar Kawin Mewaris Bersama Golongan III

Sama dengan mewaris bersama golongan ke II besar warisan dari anak luar kawin yang mendapat warisan adalah $1 / 2$ dari harta yang ditinggalkan oleh pewaris

4) Anak Luar Kawin Mewaris Bersama Golongan IV

Dalam hal anak luar kawin mewaris dengan golongan IV maka warisan yang diterimanya adalah $3 / 4$ dari harta warisan pewaris. Seperti telah disebutkan diatas hanya anak luar kawin yang diakui yang dapat mewaris terhadap harta orangtua yang mengakuinya.

\section{Komparasi Kewarisan Anak Angkat Menurut Hukum Perdata ( BW)}

Pada dasarnya, anak angkat bukanlah ahli waris yang dimaksud dalam Pasal 852 ayat (1) KUHPerdata yang menyatakan bahwa anak-anak atau sekalian keturunan mereka, biar dilahirkan dari lain-lain perkawinan sekali pun mewaris dari kedua orang tua, kakek, nenek, atau semua 
keluarga sedarah mereka selanjutnya dalam garis lurus ke atas, dengan tiada perbedaan antara laki-laki atau perempuan dan tiada perbedaan berdasarkan kelahiran lebih dulu. Namun, anak angkat dapat memperoleh warisan dengan cara diberi hibah oleh pewaris. Pemberian hibah diatur dalam ketentuan Pasal 957 KUHPerdata yang menyatakan bahwa suatu penetapan wasiat yang khusus dengan mana si yang mewariskan kepada seorang atau lebih memberikan beberapa barangbarangnya dari suatu jenis tertentu seperti misalnya segala barangbarangnya bergerak atau tak bergerak atau memberikan hak pakai hasil atas seluruh atau sebagian harta peninggalannya.

Pemberian hibah wasiat sebagai pemenuhan hak anak angkat terhadap harta waris harus dilakukan secara adil. Makna dari kata adil yaitu jika pemberian hibah tersebut memiliki nilai yang terlalu besar sehingga mengurangi hak dari ahli waris sah, maka nominalnya harus dikurangi. Sementara itu, apabila orang tua angkat adalah penghibah telah mewasiatkan ketentuan lain, maka pemberian harta berjumlah besar dapat dilakukan. Hal tersebut sesuai dengan Pasal 957 KUHPerdata yang menyebutkan bahwa apabila warisan tidak seluruhnya atau untuk sebagian diterimanya, atau apabila warisan diterimanya dengan hak istimewa akan pendaftaran harta peninggalan, dan yang ini tidak mencukupi guna memenuhi akan segala wasiat, maka hibah-hibah itu dalam keseimbangandengan besarnya, harus dikurangi, kecuali yang mewariskan tentang hal ini, telah menetapkan ketentuan-ketentuan lain dalam surat wasiatnya. Kemudian, syarat memberikan hibah kepada anak angkat yaitu hibah bersifat sukarela, membuat akta hibah di hadapan notaris dengan ditandai surat persetujuan pemberian hibah dari pewaris (orang tua angkat) dan anak kandungnya (jika ada) dan surat persetujuan tersebut harus dilegalisir oleh notaris.

Bila yang diangkat adalah anak sah, maka kedua orang tuanya harus memberikan persetujuan. Jika salah satu ada yang meninggal maka hanya diperlukan persetujuan dari orang yang masih hidup. Namun, jika orang tua yang masih hidup adalah ibu si anak dan ibu telah kawin atau kedua orang tuanya meninggal maka yang berhak memberikan persetujuan adalah wali si anak dan balai harta peninggalan (Pasal 8 sub 2a Staatsblad Nomor 129 Tahun 1917). Sedangkan apabila anak angkatnya adalah anak luar kawin maka persetujuannya harus diberikan oleh bapak dan/atau ibunya yang telah mengakuinya. Kemudian jika kedua orang tua telah 
mengakui tetapi salah satu diantaranya meninggal maka persetujuannya dari bapak atau ibu yang masih hidup. Sementara itu, jika bapak dan ibunya tidak mengakui atau keduanya meninggal dunia maka persetujuannya adalah wali si anak dan balai harta peninggalan (Pasal 8 sub 2b Staatsblad Nomor 129 Tahun 1917).23

\section{Penutup}

Anak zina adalah anak yang lahir dari suatu perbuatan zina, yaitu hubungan kelamin antara laki- laki dengan perempuan yang tidak terikat dalam nikah yang sah meskipun ia lahir dalam suatu perkawinan yang sah, dengan laki-laki yang melakukan zina atau laki- laki lain. Dalam hukum Islam anak zina disebut dengan anak mula'anah yang mana anak tersbut tersebut anak yang berasal atau yang dilahirkan dari hubungan yang tidak diakui oleh agama dan hukum atau biasanya disebut dengan anak haram. Dalam hukum Islam anak zina mempunyai hak atas waris kepada ibunya.

Pengangkatan anak adalah suatu perbuatan atau tindakan pengambilan anak orang lain ke keluarga sendiri sedemikian rupa sehingga antara orang yang memungut anak dan anak yang dipungut itu timbul suatu hukum kekeluargaan yang sama seperti yang ada antara orang tua dengan anak kandungnya sendiri. Namun menurut hukum Islam, anak angkat tidak dapat diakui untuk bisa dijadikan dasar dan sebab mewarisi, karena prinsip pokok dalam hukum kewarisan Islam adalah adanya hubungan darah atau keturunan. Dengan kata lain bahwa peristiwa pengangkatan anak menurut hukum kewarisan, tidak membawa pengaruh hukum terhadap status anak angkat, yakni bila bukan merupakan anak sendiri, tidak dapat mewarisi dari orang yang telah mengangkat anak tersebut.

Maka sebagai solusinya menurut KHI adalah dengan jalan pemberian wasiat wajibah dengan syarat tidak boleh lebih dari $1 / 3$ (sepertiga).Di dalam Kitab Undang-Undang Hukum Perdata anak dapat digolongkan menjadi 2 golongan Dari kedua golongan anak berdasarkan Kitab Undang-Undang Hukum Perdata tersebut diatas hanya anak sahlah yang bisa menjadi ahli waris dari orangtuanya. Sedangkan untuk anak tidak sah mereka tidak bisa mewaris. Namun berdasarkan Pasal 272 KUHPerdata dapat diketahui bahwa dalam hukum Perdata terdapat anak

${ }^{23}$ Berlino Askandar Tjokroprawiro, 'Perlindungan Hukum Anak Angkat Menurut Hukum Positif Indonesia' (Fakultas Hukum Universitas Airlangga 2007). hlm. 44-45 
yang dapat dilakukan pengakuan. Berdasarkan BW anak angkat bukanlah ahli waris yang dimaksud dalam Pasal 852 ayat (1) KUHPerdata. Namun, anak angkat dapat memperoleh warisan dengan cara diberi hibah oleh pewaris. Pemberian hibah diatur dalam ketentuan Pasal 957 KUHPerdata.

\section{Daftar Pustaka}

Abdul Manan. Aneka Masalah Hukum Perdata Islam di Indonesia. Jakarta:Kencana, 2006.

Ahmad Kamil, dan Fauzan. Hukum Perlindungan dan Pengangkatan Anak di Indonesia. PT Raja Grafindo: Jakarta, 2010.

Ahmad Rofiq. Fikih Mawaris. Edisi Revisi, Jakarta :PT Raja Grafindo Persada, 2002.

Amir Syarifuddin. Hukum Kewarisan Islam. Jakarta : Kencana 2004.

Berlino Askandar Tjokroprawiro. Perlindungan Hukum Anak Angkat Menurut Hukum Positif Indonesia'. Fakultas Hukum Universitas Airlangga 2007.

Fatchur Rahman. Ilmu Waris. Bandung: AlMa'arif, 1994.

Muhammad Ajib. Perbedaan Antara Hibah, Wasiat, dan Waris. Jakarta Rumah Fiqh Publishing, 2020.

Muhammad bin Abdurrahman al Dimasyqi. Fiqh Empat Mahdzab. Bandung: Pustaka Ilmu, 2014.

Muhammad bin Shalih al-Utsmaimin, Panduan Praktik Hukum Waris. Jakarta: Pustaka Ibnu Katsiir, 2012.

Muhammad Nashiruddin al-Albhani. Shahih Sunan at Tirmidzi. Terj. Fachrurazi. Jakarta: Pustaka Azzam, 2006.

Komite Fakultas Syariah Universitas Al-Azar. Hukum Waris. Jakarta: Senayan Abadi Publishing, 2009.

https:// kalam.sindonews.com/ayat/4/33/al-ahzab-ayat-4

https://kalam.sindonews.com/ayat/180/2/al-baqarah-ayat-180 